\title{
Learning approaches of Indonesian EFL Gen Z students in a Flipped Learning context
}

\author{
Made Hery Santosa \\ mhsantosa@undiksha.ac.id \\ Universitas Pendidikan Ganesha \\ Jalan A. Yani No 67 Singaraja, Bali, Indonesia
}

Received: January 8, 2017; Accepted: September 23, 2017; Published: September 30, 2017

\begin{abstract}

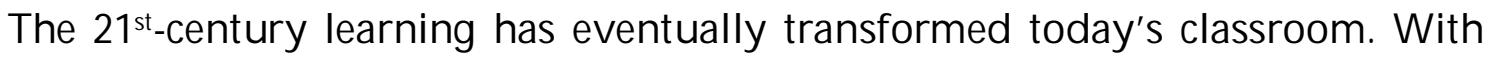
more digital natives in the class, both educators and students face a changing classroom that should accommodate different learning paces, styles and needs. This study aimed at helping students in becoming English as Foreign Language (EFL) competent in-service teachers. Using Flipped Learning, the study utilizes four FLIP pillars into EFL learning, namely Flexible environment, Learning culture, Intentional content, Professional educators. The study employed three instruments, namely survey, tests, and interview. The result of tests showed a promising students' progress from low to high achievement. The survey showed that students tended to perform deep approaches to learning while findings from the interview provided more interesting phenomena underlying students' motives in their learning approaches, involving dynamic power distance relationship between lecturer and students. Heavier task loads and learning model familiarity have been highlighted. Effective socialization of the model using technology and sustainability of use of the model are suggested.
\end{abstract}

Keywords: learning approaches, EFL, Gen Z, Flipped Learning

How to cite this paper: Santosa, M. H. (2017). Learning approaches of Indonesian EFL Gen Z students in a Flipped Learning context. Journal on English as a Foreign Language, 7(2), 183-208.

As more students of digital natives enroll in today's classrooms, the nature of university business is changing in the directions in the global economy recently. High global competition has made tertiary institutions expand their scope and 
restructure their teaching and learning approaches (Biggs, 2003; Campbell, 2012; Rohaniawati, 2011). Tertiary education has focused on producing more graduates ready to meet the needs of the jobs market in the knowledge-based economy (Campbell, 2012; Phusavat, Ketsarapong, Ooi, \& Shyu, 2012). However, as they expand and restructure, universities have faced further challenges, with larger classes and more diversified student populations. Issues include ability, motivation, age, prior knowledge and expectation (Altbach, Reisberg, \& Rumbley, 2009; Biggs \& Tang, 2011). Therefore, knowing more about the learning attributes that shape effective learning is an essential element for facilitating students' learning needs.

Students' approaches to learning are considered important dynamic attributes that assist students in the learning process (Ausubel, 1968; Biggs, 1978, 2003; Emilia, Bloomfield, \& Rotem, 2012; Marton \& Säljo, 1976; Ramsden, 1992; Schmeck, 1983; Thomas \& Bain, 1984; Wittrock, 1974). It was initiated in about three decades ago by the work of Marton and Säljo (1976). Their work is considered a breakthrough in understanding student learning processes when completing a particular learning task. Their study indicated that, depending on the learning context, students develop particular learning orientations. Students may intend to learn at a 'deep' level, that is, establishing mastery and integration of the materials into their existing knowledge base, or they may learn in a 'surface' way, that is, achieving short-term memorization of the material so it may be reproduced (Cuthbert, 2005; Marton, 1981; Marton \& Säljo, 1976, 1984).

Numerous subsequent studies have discussed Marton and Saljo's interesting findings (Ananda, 1997; Beattie, Collins, \& McInnes, 1997; Biggs, 1987, 1989a, 1989b; Boyce, Williams, Kelly, \& Yee, 2001; Choo, 2005; Cuthbert, 2005; Dharma, 1997; Emilia et al., 2012; Emilia \& Mulholland, 1991; English, Luckett, \& Mladenovich, 2004; Entwistle, 1991, 2004, 2009; Entwistle, Hanley, \& Hounsell, 1979; Entwistle \& Ramsden, 1983; Entwistle \& Tait, 1990; Halawi, Mccharty, \& Muoghalu, 2009; Hall, Ramsay, \& Raven, 2004; Hay, 2007; Lucas, 2001; Lucas \& Mladenovic, 2004; Marton \& Säljo, 1976, 1984; Taher \& Jin, 2011). A general pivotal concept found in these studies is that in learning some students can be very passionate to learn and understand what they are learning (that is, the deep approach), while others will only do the minimum work to meet the requirements of the subject (that is, surface learning) (Biggs, 1999). Since the ideal of academic inquiry corresponds to a deep approach to learning, the goal of good teaching and learning should be aimed at the promotion of deep learning engagement (Trigwell \& Prosser, 1991; Warren \& Griffiths, 2006; Watkins, 1983). However, while the teaching-learning process expects 
conceptual changes, many students continue to fail to achieve the desired understandings. They tend to list facts rather than relate them.

Studies in the Asian context have found that students' approaches to learning are more directed to towards a surface learning approach (Cheng, 2000; On, 1996; Watkins \& Biggs, 1996). On (1996) found that the learning system in many Asian countries, including China, Japan, and Korea, evidenced practices of rote learning and memorization. Students were also reported to have a better ability in receptive skills rather than productive skills (Watkins \& Biggs, 1996). In learning English as a Foreign/Second Language (EFL/ESL), Cheng (2000) found that Asian learners tended to be reticent and passive. As learning in higher education normally requires more self-monitoring and a selfregulatory learning style, surface approaches may affect the quality of learning.

A similar result is also found in the Indonesian learning context. Studies reported that in the higher education context of Indonesia, university students tend to perceive success in their academic context as principally requiring a surface-level approach to learning (Emilia \& Mulholland, 1991; Ismail, 2009; Santosa, 2013; Watkins, 1996). They also highly respect teachers' knowledge and authority (Rohaniawati, 2011). Studies indicate that students lean towards surface approaches to learning including rote memorization, low critical thinking skills, and passive, compliant, unreflective learning rather than deep approaches (Ananda, 1997; Dardjowidjojo, 2001, 2006; Elsegood, 2006; Hadisaputra \& Santosa, 2008; Iftanti, 2012; Masduqi, 2011; Nilan, 2003; Pikkert \& Foster, 1996; Putrayasa, 2001; Santosa, 2008, 2012; Suharmanto, 2003). Students seem to focus more on academic achievement rather than on the generic capabilities such as critical thinking, problem-solving, leadership, communication, and reflection (Hardiyanto, 2010; Sayuti, 2009; Tambunan, 2011).

Some factors are believed to influence the aforementioned issues. The fact that the education system in Indonesia has been centralized since Independence Day in 1945 has potentially contributed to the prevalence of the surface-level learning approach in the Indonesian context. Through these revisions, the government tried, unsuccessfully, to decentralize the learning process for English learning from the grammar-translation method to the conversational approach in 1984 (Lie, 2007), and most recently into a more learner-oriented teaching approach that stimulates curiosity and enhances discovery (Masduqi, 2011; Suharmanto, 2003). Learning directed towards a deeper type, in which students are expected to understand and take what was learned in one situation and to apply it to new situations, is a major challenge for Indonesian teachers (Hadisantosa, Huong, Johnstone, Keyuravong, \& Lee, 2010; National Research Council, 2012). 
Another influencing issue comes from the cultural dimension that Asian, including Indonesian, has. According to Joy and Kolb (2009), culture plays an important role in the way individuals learn. Chinese Confucian-oriented learning, for instance, teaches students to respect and obey authorities, such as teachers (English et al., 2004), and to learn through passive, rote memorization (Biggs \& Rihn, 1984). Teachers are normally regarded as the main source of knowledge. They are considered as the authorities in the classroom and thus given great respect. This creates a single, right answer practice; there is no opportunity for students to utilize alternative rich sources of information or to respond from multiple perspectives.

Indonesian learning views have parallels to the Confucian view. Dardjowidjojo (2001) argues that the societal system in Indonesia, particularly in Java, is based on rank, social status, and age. The higher the rank, the higher the social status; and the older the person, the more respect is given. This is expressed in three views. The first view, manut-lan-minurut, means 'to obey and to follow the elders', like teachers or parents. The éwuh-pekéwuh view means 'uncomfortable and uneasy', whereby people with lower careers and social castes feel uncomfortable and uneasy about opposing their elders. A student, for example, would be reluctant to oppose the teacher's view, even when it is not right. Finally, the sabda-pendita-ratu is concerned with 'an act of not questioning the words of the priestly king'. Originally, this was intended to encourage leaders to be very careful in what they said. However, it has a different meaning nowadays. Simply put, higher-ranked people such as teachers are regarded as founts of knowledge, who require a single correct answer in response to a particular issue (Novera, 2004).

Bali also has a particular cultural view of personal hierarchy. Held views such as koh ngomong, sekadi merebut balung tanpa isi and de ngaden awak bise, depang anake ngadanin are some of them (Echa, 2008; Sunarta, 2009; Tantrayana, 2012). The first view simply means 'being reluctant to talk'; that is, being reluctant to participate in someone else's business, especially if it does not relate to or give benefit to one's self. The idea of respect for others seems fundamentally good. However, in classroom practice in Bali, many students find themselves not eager to participate. They might consider it inappropriate to interfere or participate because they do not see any benefit for themselves. In relation to the teacher's authority, students also feel it is not polite to challenge teachers' opinions. The second view literally means 'like quarrelling for something unworthy'. This is a metaphor referring to dogs quarrelling for a bone (without meat). In Balinese classroom practice, this may develop into an avoidance of debate or intense discussion, to be safe from any potential consequences. Finally, the last view means 'never praise yourself, let others do 
that'. It encourages a person not to become arrogant. However, in practice, it causes people to become introverted, passive and silent during learning activities, to avoid having others think that they are arrogant.

This contrasts with Western traditions in which people are taught from an early age that it is very important to evaluate people's ideas, things or experiences by incorporating personal judgments on them (Elsegood, 2006; Elsegood \& Rahimi, 2009). This difference shows how culture may shape students' learning styles. Thus, in contrast to the views influencing Balinese learners, learning in the Western context is more directed towards information exchange.

These differences have been identified by Hofstede (1980) in his early study as attributes of culture that linger within an individual's particular society. He conducted a large-scale survey database on several themes, including dependence on superiors, need for rules and predictability, the balance between individual goals and dependence on the company and the balance between ego values and social values (Hofstede, 2011, p. 7). Followed by several other studies, it was found that culture can play a significant role in the ways in which an individual learns in particular learning contexts (Cronjé, 2011; Hofstede, 1980, 1986, 1991, 2001, 2011; Signorini, Wiesemes, \& Murphy, 2009; Thowfeek \& Jaafar, 2012).

A complex mixture of factors including the centralized mechanism, teaching practices, learning behaviors and social contexts, currently shapes the English teaching and learning context in Indonesia. With a score of only 0.689 on the human development index (based on the Human Development Index report of 2016), Indonesia is currently positioned at 113 out of 187 countries and territories in the world. With the current rapid development of the global economy, Indonesian university graduates are reported to be far from satisfying job market demands (Sayuti, 2009). Attempts have been made to shift from product- to process-oriented learning. Teaching and learning processes put emphasis on assisting students to become self-directed and independent individuals and to be active rather than passive participants in teaching and learning processes (Suharmanto, 2003). Further, the teacher should be a facilitator rather than an authoritative agent (Marcellino, 2008). However, these changes are rare in Indonesian classroom practice.

While the redesign of teaching materials, assignments and assessment tasks to promote learning resolves part of the problem, without a corresponding shift in students' approaches to learning, which are influenced by students' orientation to studying, these cannot be effective. For students with a preference to adopt a surface approach to learning, even the most supportive learning context will not be adequate to encourage them to adopt a 
deep approach (Biggs \& Rihn, 1984; Kember \& Gow, 1989; Marton \& Säljo, 1984; Ramsden, 1992, 2003). Therefore, it is important to provide learning activities and assessments that require the demonstration of understanding, analysis, and critical evaluation, to discourage a tendency toward a surface approach (Biggs, 1985; English et al., 2004; Laurillard, 1984; Ramsden, 1992).

To investigate the learning situation further, this study developed an intervention on student learning, with innovative learning practices aimed at engaging students more deeply to foster their learning quality. Since students' application of a surface approach to learning consequently affects their learning outcomes and performance on tasks requiring higher cognitive abilities, an emphasis on students' ways of processing information into new knowledge for application is very important. Inquiry-based learning facilitates this process. Student-centred learning emphasizes that students ask questions to obtain information (Deutsch, 2005). In inquiry-based learning, students exercise research skills as part of an inquiry learning cycle involving observation, query, hypothesis proposal, data gathering and conclusion (Gredler, 1997; Justice et al., 2007; Putrayasa, 2001; Sincero, 2006; Sund \& Trowbridge, 1967; Volkert, 2012; Zhu \& Zou, 2011). As inquiry-based learning uses authentic situations, it challenges students to view and solve real-life problems (Feletti, 1993; McKenzie, 1998).

The students today are different from those who were born before the 1990s. These Gen Z were born with technology already with them. In today's rich technology environment, having Gen $Z$ students practice inquiry-based learning is important to help them to perceive issues from multiple perspectives, analyze them and construct new knowledge to gain an understanding of the issues (Wilson \& Jan, 2003). There is rich information available with quick access, and teaching and learning process should be directed to a critical perspective rather than receptive one only. Apart from producing high-quality learning outcomes (Trigwell \& Prosser, 1991), learning in higher education should also aim to produce effective independent learners (Baird, 1988).

Inquiry-based learning was utilized by Schoology, a Learning Management System that serves as the Flipped Learning model. It assists students to become the agents of their own learning rather than the object of instruction (Hamdan, McKnight, McKnight, \& Arfstrom, 2013). Flipped Learning also provides the bridge to a learner-centered classroom environment, thereby enabling deeper learning that educators are seeking (Bergmann \& Sams, 2012). Its procedures are that teachers prepare the materials in the form of videos (or reading materials) prior to the class meetings, students study them and bring to the class discussion with teachers facilitate the discussion, 
conclusions are reached, new tasks are given for new applications based on the understandings (Bergmann \& Sams, 2012; Lang, 2017).

Therefore, the present study had two aims. The first was to investigate students' approaches to learning in an English education department in one university in Singaraja, Bali, Indonesia. An attempt was made to relate the study findings to previous studies such as those of Emilia and Mulholland (1991), Watkins (1996), Nilan (2003), Ismail (2009) and Emilia et al. (2012). Since there are limited studies on Indonesian student learning, this study aimed to contribute to the literature in this area. The second aim was to conduct an intervention in selected English subjects in the English education department, to determine whether there is a significant difference in student learning outcomes before and after inquiry-based learning aided by flipped learning was implemented. Potential challenges influencing students' approaches to learning and possible ways to cope with these challenges were observed during the intervention. This study is limited to Writing course. As a productive language skill, being competent in expressing ideas in a written scientific mode requires higher order thinking skills as required in the framework.

\section{METHOD}

A mixed-method approach was used to achieve the research aims. Mixed-methods research studies use both quantitative and qualitative data collection and analysis (Creswell \& Clark, 2011; Greene, Caracelli, \& Graham, 1989; Teddlie \& Tashakori, 2003) and this can be a means of compensating for the weaknesses inherent in the other (Creswell, 2009). By using a concurrent triangulation strategy, the research was designed to provide views that were more comprehensive. The multiple views can provide an insightful profile of student approaches to learning in the investigated context. This sequential procedure allows the study to increase the reliability and validity of the instruments. Data findings were discussed to build stronger inferences, as they would provide triangulation of data by examining research questions from two different points (Cohen, Manion, \& Morrison, 2011; Creswell, 2009; Creswell \& Clark, 2011; Greene et al., 1989; Teddlie \& Tashakori, 2003).

There were 151 students participating in this study. There were two groups involved. Both studied several intriguing topics in an inquiry-based learning framework. Only one group was aided by Schoology as a flipped learning delivery. The instruments used in this study were revised Study Process Questionnaire (SPQ), EFL learning tests, Structure of the Observed Learning Outcome (SOLO) taxonomy rubric, and semi-structured interview guides for the student participants. The questionnaire used in this study was the revised version of the R-SPQ-2F (Biggs, Kember, \& Leung, 2001). The 
Cronbach's Alpha values for R-SPQ-2F were found to be reliable, they were .73 for the deep approach and .64 for the surface approach respectively. Biggs et al. (2001) stated that all the scales passed the goodness of fit test. Another instrument used in this study was English-learning tests. These tests were given to the participants in the research at the beginning of the semester (pre-test) and at the end of the semester (post-test), together with the questionnaire. Both tests given were the same and open-ended. They required the students to produce responses and complete written texts with a minimum 250 words. To maintain validity and reliability, the tests were taken from selected International English Language Testing System (IELTS) tests. According to Uysal (2010, p. 6), items in the IELTS test have passed the goodness of fit test and are therefore reliable. However, careful consideration needed to be given to the cultural differences of the test takers.

The students' written responses on the tests were analyzed using the SOLO taxonomy rubric. Students' responses to particular learning tasks were used to categorize whether students' responses were the pre-structural, unistructural, multi-structural, relational or extended abstract level (Biggs \& Collis, 1982). Moreover, a semi-structured interview was conducted to 15 volunteer group students. The students' responses were analyzed descriptively based on themes, such as student approaches to learning, socio-cultural influences, learning outcomes and ICT influence.

There were three main stages conducted during the data collection, they were a questionnaire and writing a response of the English-learning tests (Stage I), the intervention of inquiry-based learning aided by flipped learning (Stage II), and semi-structured interviews (Stage III). The questionnaire and tests were given at the beginning and at the end of the semester as pre- and post-test activities. The interviews were conducted at the end of the intervention. All data collection procedures were conducted in Indonesian, which was the students' mother tongue. The obtained data were then analyzed using an independent-samples $t$-test to evaluate the effectiveness of the learning instruction. The students' responses were analyzed using SOLO taxonomy rubric and the interview was transcribed and analyzed using qualitative methods.

\section{FINDINGS}

From the data gathering, there were interesting results found. First was about students' approaches to learning, the second was about the intervention's results, and third was from the interview results. 


\section{Student Approaches to Learning} Table 1.

The result of the student approaches to learning survey is presented in

Table 1. Students' Approaches to Learning Score

\begin{tabular}{lllll}
\hline Tests & Pre-test & \multicolumn{3}{c}{ Post-test } \\
\hline Learning Approaches & Deep & Surface & Deep & Surface \\
& & & & \\
\hline $\mathrm{N} \quad$ Valid & 151 & 151 & 151 & 151 \\
\hline Mean & 35.45 & 23.11 & 35.05 & 24.03 \\
\hline Std. Dev. & 4.728 & 6.555 & 4.968 & 6.653 \\
\hline
\end{tabular}

Table 1 shows that the mean scores for the deep approaches were higher than for the surface approaches, in the pre-test and post-test. The mean score deep approach in the pre-test (35.45) was higher than the surface approach in the pre-test (23.11). In the post-test, the mean scores were higher for the deep approach. The mean score for the deep approach in the post-test (35.05) was higher than for total surface approach in the post-test (24.03). This reveals that the students' approaches to learning tended to be deep. Students aimed to learn for understanding of concepts.

\section{Students' Learning Outcome}

An independent-samples t-test was carried out to compare the mean score of learning outcomes in the experimental and control groups. The results of the independent-samples t-test for students' pre-test is presented in Table 2 and Table 3.

Table 2. Independent-amples t-test on pre-test scores-Group Statistics

\begin{tabular}{llllll}
\hline Group Statistics & \multicolumn{5}{l}{} \\
\hline & $\begin{array}{l}\text { Experimental and Control } \\
\text { Groups }\end{array}$ & \multirow{2}{*}{ Mean } & $\begin{array}{l}\text { Std. } \\
\text { Deviation }\end{array}$ & $\begin{array}{l}\text { Std. Error } \\
\text { Mean }\end{array}$ \\
\cline { 2 - 6 } Pre-test scores & Experimental Group & 63 & 1.05 & .215 & .027 \\
\cline { 2 - 6 } & Control Group & 88 & 1.08 & .272 & .029 \\
\hline
\end{tabular}

In Table 2, the experimental groups' mean score (1.05) was slightly similar than for the control group (1.08). Furthermore, the result of the independent-samples t-test in the pre-test is presented in Table 3. 
Table 3. Independent-samples t-test on pre-test scores-Result

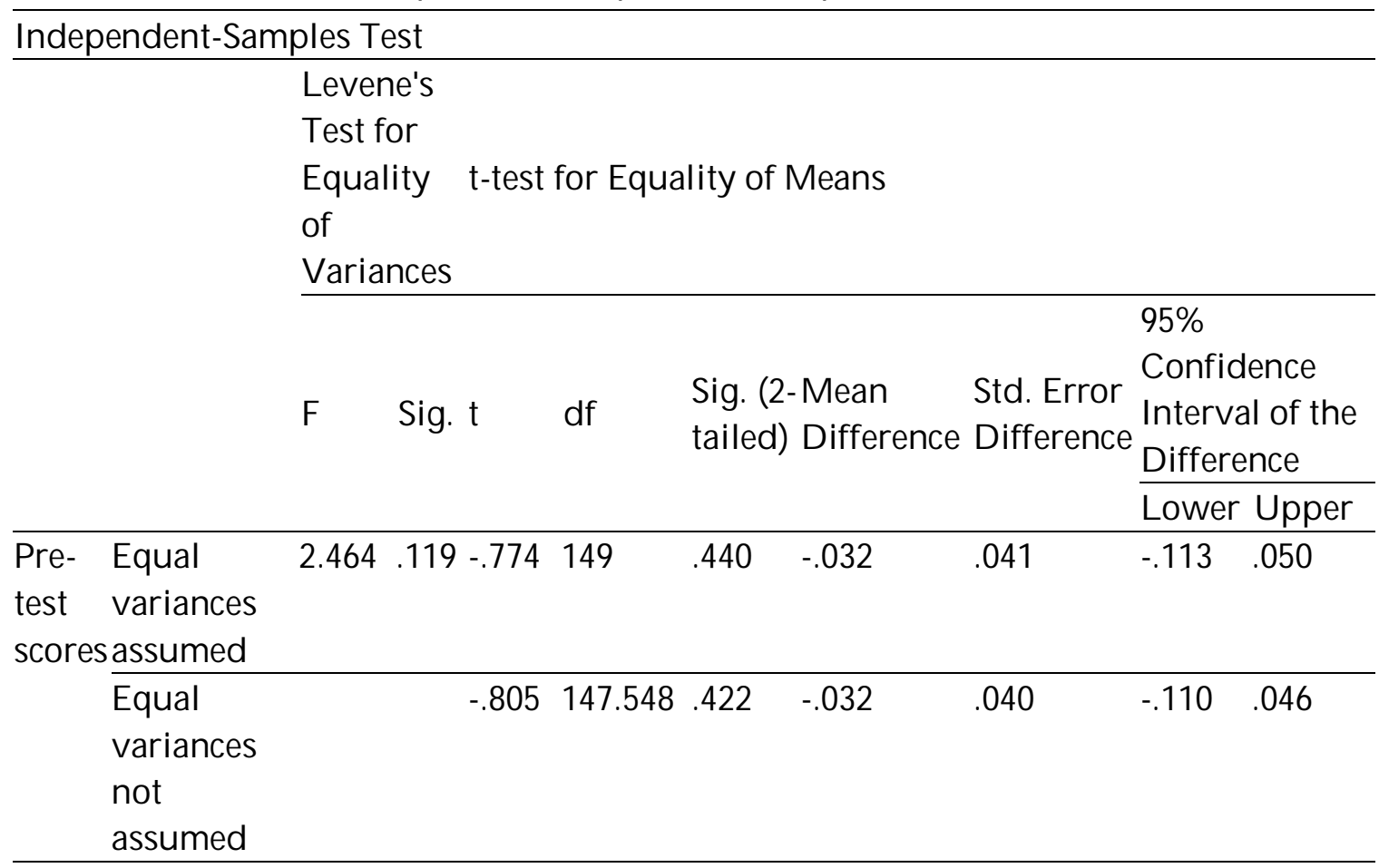

As shown in Table 3, in comparing the learning outcomes between the experimental and control groups, there was no significant difference in mean scores for the experimental group $(M=1.05, S D=.215)$ and the control group $(M=1.08, S D=.272 ; t(149)=-.774, p=.440$, two-tailed $)$. The mean difference was $-.032,95 \% C I=-.113$ to .050 , in a small effect size (eta squared $=.063$ ). There was no significant difference between the experimental group and the control group students, for having only $6 \%$ of the variance explained. This shows that the groups were similar before the study was conducted.

The data analysis further looked at students' learning outcomes in the post-test. Tables 4 and 5 present the result of the independent-samples t-test on the post-test.

Table 4. Independent-samples t-test on post-test scores-Group Statistics

\begin{tabular}{llllll}
\hline Group Statistics & $\begin{array}{l}\text { Experimental and } \\
\text { Control Groups }\end{array}$ & $\mathrm{N}$ & Mean & $\begin{array}{l}\text { Std. } \\
\text { Deviation }\end{array}$ & $\begin{array}{l}\text { Std. Error } \\
\text { Mean }\end{array}$ \\
\cline { 2 - 6 } Post-test & $\begin{array}{lllll}\text { Experimental Group } \\
\text { scores }\end{array}$ & 63 & 2.91 & .768 & .097 \\
\cline { 2 - 6 } Control Group & 88 & 1.39 & .490 & .052 \\
\hline
\end{tabular}

At the end of the semester, it was found that the mean score for the experimental group was higher (2.91) than for the control group (1.39). The 
independent-samples t-test in the post-test was further carried out to examine the changes (see Table 5).

Table 5. Independent-samples t-test on post-test scores-Result

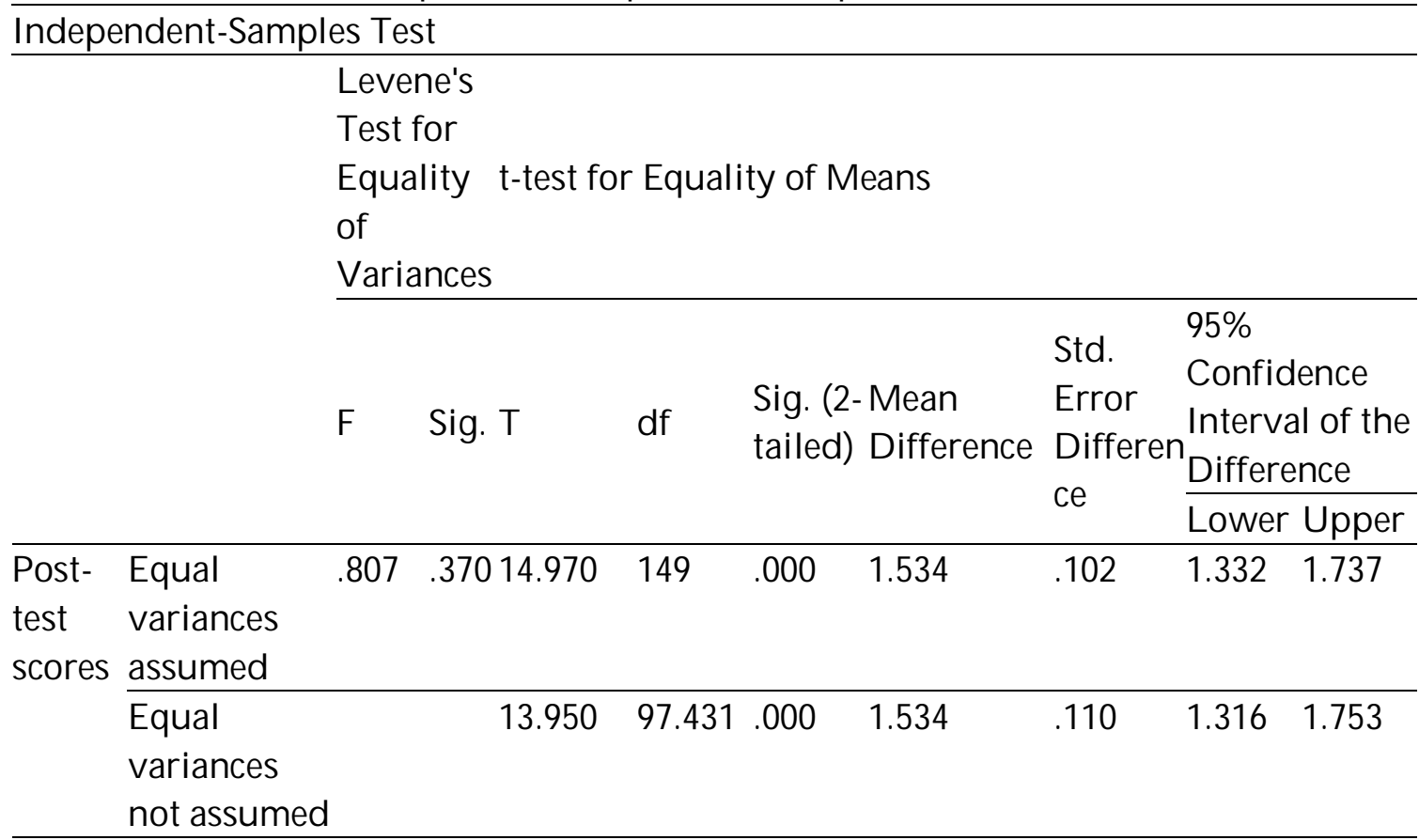

The result shows that an independent-samples t-test was conducted to compare the learning outcomes between the experimental and control groups after the experimentation. There was a statistically significant difference in scores for the experimental group $(M=2.91, S D=.768)$ and the control group $(M=1.39, S D=.490 ; t(149)=14.970, p=.000$, two-tailed $)$. The mean difference was $1.534,95 \% C I=1.332$ to 1.737 , in a large effect size (eta squared $=.78$ ). This result shows that there was a significant difference in students' learning outcomes after the study ended, with the experimental group showing a larger improvement. The result also reveals that a large percentage $(78 \%)$ of the variance was explained in the data findings.

To summarise, a statistically significant difference benefited the experimental group in the present study was found. Inquiry-based learning aided by flipped learning influenced students' learning outcomes.

\section{DISCUSSION}

Findings from the survey revealed that students' approaches to learning tended to be in the deep direction. Findings from tests analyzed by SOLO taxonomy rubric also confirmed the broad pattern of the learning approaches shown in the research context. These findings were in line with several existing studies. Ismail (2009) previously found that majority of Accounting students in 
Indonesia has a tendency of deep learning approach. A similar supporting result came from Emilia et al. (2012) with a learning approach research to medical students. These existing Indonesian research findings confirmed the results in this study. As students in Bali were found to practice deep learning approach, they learn for understanding concepts. However, contrasting results also emerged from some studies. Watkins (1996) found that Indonesian students had a tendency to believe that academic success was based on surface learning approaches. Supporting this, Jürgens, Emilia, and Widyandana (2009) also found that the majority of medical students employed a surface approach to learning. Likewise, Taher and Jin (2011) found that MBA students in China had to shift from a strong rote learning approach towards learning for understanding. These different findings raised the question of whether students' questionnaire responses reflected their real preferences.

To confirm the tendency towards deeper learning approach, a follow-up focus-group interview was conducted. A further check was needed to understand more about the approaches, especially whether the shared deep approach during the survey was as valid as it appeared to be.

Given the context, reasons for these findings are at best speculative. The most useful data for interpreting the responses came from the interview results. The results of the interviews suggest that the survey results should be interpreted cautiously. Student 1 , for example, admitted that he wanted to have a good image of himself. He also said that he did not understand the instructions:

Previously, I did not understand the questionnaire, Sir. So, I answered [to show] a good image [of myself]. (Student 1; Male)

Student 2 reflected the same motivation, saying:

I want to appear good in front of other people. (Student 2; Female)

The interviews also revealed that some students had to work hard to understand particular questionnaire items. Even though careful preparations had been made to produce a valid and reliable questionnaire, students still found it difficult. As exemplified in the following quotation, although Student 6 did not understand the construct, he knew the expectations for good and effective learning as asked in the survey items. That is, he knew that in Western schools, students are expected to be active and engaged in the learning process:

I know from the information from the Internet that English culture is normally direct, critical, and open. I see some survey items ask this kind of learning. (Student 6; Male) 
These examples show that pre-emptive factors influenced students' perceptions of their learning approaches. As Ismail (2009) found, even though students claimed that they approached their learning in a deep fashion, their responses might not reflect their actual approaches since they tended to respond in a way they thought would be desired. Fang (2003) mentioned this as 'face-saving'. This element is salient in Asian cultures including Indonesian (Fang, 2003; Yorra, 2012).

This situation is best explained using what Bhabha (1983) describes as a group perception or stereotype. According to Bhabha, a particular group of people, such as Westerners, may look at a particular geographical and racial group, such as Easterners, as a different group with its own characteristics. These 'cultural assumptions' (Said, 1977) seemed to be employed by the research participants to accommodate the research requirement. Since they experience English as a representation of Western culture, they are aware of stereotypes of learning associated with that culture; for instance, critical thinking, open discussion, and higher-order cognitive processes. With this new insight of different cultural representations, it needs to be considered that students tried to project the expected image. Therefore, the results indicating an inclination toward a deeper approach may not be as straightforward as they initially appear.

Culturally held views which are latent in individuals (Echa, 2008; Sunarta, 2009; Tantrayana, 2012), also appeared to contribute to the students' performance. Despite their responses to the questionnaire, the students showed a reluctance to participate in the teaching and learning activities. For these Indonesian students, socio-culturally derived preferences not to confront higher authorities may have impeded students' participation in open discussions. Although most also attempted to learn actively, students still faced impeding issues coming from dominant peers or teachers. In many instances, students were reluctant to speak because of these pressures. Student 10, for example, said that she was concerned with other people's reactions towards her attempt to speak in the classroom:

[I am also] worried with how my friends might respond, scared to be told wrong, to be mocked. For me personally, I was shy. Also, I wasn't used to speaking well so whatever came into my head I just said it so I couldn't control the grammar. (Student 10; Female)

The students tended to be submissive to the teachers' transfer of knowledge and information. They avoided direct debates. This clearly demonstrated students' reluctance to exchange information with higher-ranked Journal on English as a Foreign Language, 7(2), 183-208 Copyright $\odot 2017$ by JEFL, p-ISSN 2088-1657; e-ISSN 2502-6615 
people, such as lecturers (Hofstede, 1980, 1986, 2011; Lewis \& George, 2008). As students respected higher authorities, their responses to the questionnaire suggest that they sought to perform in the manner they perceived they were expected to in the current investigation (Dardjowidjojo, 2001). Hofstede, Hofstede, and Minkov (2010) have found that culturally, this example of the characteristic shown by the students above exists in a nation that has high Power Distance index, such as East European, Latin, African countries and lower for Germanic and English-speaking Western countries and Asian, including Indonesia. Therefore, although they were informed that their responses would not influence their scores, they maintained their high respect for authority.

These cultural issues are strong. Thus, higher-ranked people, such as teachers, are always regarded as experts in terms of knowledge and accorded high respect. Students seek to avoid making mistakes, perceived by them as likely due to their expectation of one correct answer for each question (Nesama, 2012). They were uncomfortable with something not certain, what Hofstede called as Uncertainty Avoidance (Hofstede, 2011). In the Indonesian context, these widely held cultural views are believed to affect students' perspectives on learning. The Javanese cultural views detailed by Dardjowidjojo (2006) and the Balinese cultural perspectives presented earlier (Echa, 2008; Sunarta, 2009; Tantrayana, 2012) explain why passivity and acceptance were so common among students in the teaching and learning activities. However, other influences on students' behavior were also reported. For example, Student 13 explained:

What often happened, ..., that sometimes we wanted to speak up, ..., the lecturer tends to object and judge the students' opinion. So, the students later felt reluctant to speak up again. ..., so, what's the point of sharing opinion if it was never accepted? (Student 13; Male)

An interesting finding was that the students were trying to participate in the new program, but were impeded by lecturers' actions. According to the response of Student 13, early in the semester, the students found themselves afraid of making mistakes or being blamed for lacking relevant knowledge in the teaching and learning activity. This discouraged them from being active in classroom activities. The high authority level of the lecturers may be one of the reasons why students were passive. Many students felt uncomfortable appearing to oppose the higher authority of the lecturer, even when they had ideas to share in the classroom activities (Dardjowidjojo, 2001, 2006). 
In this study, the researcher accompanied the students during data collection. Students may reasonably have assumed that the researcher would not be investing effort in exploring a non-worthwhile topic. Consequently, they may have perceived the desired outcome of the study as to suggest that students reflected a view 'different from what we are most familiar with'. Helping the researcher would amount to identifying answers that appeared to fit a stereotype of Western values or that were different from the familiar (Bhabha, 1983; Dardjowidjojo, 2006). Thus, while the questionnaire data may inflate the strength of a preference for deep learning, the SOLO results show that over the course of the intervention a significant change was achieved in the behavior of the experimental group.

As the experiment used Schoology, teaching and learning activities employed many online resources to assist students' learning. Students actively watched videos or read materials before the class discussions and used computers mostly in an online learning environment. Both students and lecturers were required to equip themselves with materials and highlight those to bring into the classrooms. According to some students, using Schoology brought several advantages in the teaching and learning activities. Student 14, for example, said that the online learning mode assisted him in improving his English proficiency.

The strength of using E-Learning for me is I can practice my English by using E-learning. I can share some activities and comment on my friend's post. By using E-Learning, I am able to understand information that the lecturer gives to me and my friend. (Student 14; Male)

The above comment was strengthened by Student 9's comment:

From my perspective, I found that this course has a good influence on my writing skill. I personally think that Schoology is a good medium for my writing skill. I can see the improvement in myself now; I have become more confident in arranging my ideas in writing. (Student 9; Female)

Student 12 endorsed the same view that Schoology usage also enabled the students to learn without being limited by time and space:

By using the Schoology, the students can study everywhere at any time. (Student 12; Female)

Several studies have been conducted on student-centered learning processes using online learning (Brine, Wilson, \& Roy, 2007; Dang, 2012; Hsieh, 
2009; Nandi, Hamilton, Chang, \& Balbo, 2012; Yamauchi, 2010). Online learning has been reported as successful in providing more input and insight for students in the learning process. However, there are also several caveats in using this kind of technology. Student 15 asserted that infrastructure and cost were big issues for students:

... I like use E-learning as a medium to learn the language but, there are many weaknesses in using E-learning especially in Indonesia. .... If I want to access this web, I have to wait for a long because the loading is very slow. The other weakness is spending a lot of money. (Student 15; Female)

Technology is an important element in the current study. It can assist effective teaching and learning. When there was limited infrastructure and access, the technology could be a challenging issue. Tackling the matter effectively was necessary to accommodate better teaching and learning processes.

\section{CONCLUSION}

The study investigated students' approaches to learning in Indonesian English learning when utilizing inquiry-based learning aided by flipped learning. These approaches are an important aspect of learning and help to shape 'how much' and 'how well' learning is done by each individual. It was found that learning activities that support higher-order thinking processes can direct students' learning approaches towards deeper learning and can thus minimise the gap between lower and higher cognitive ability. Effective use of different learning spaces, such as face-to-face and online learning, can provide improved interaction, collaboration and continuous feedback opportunities for students, helping them to reflect on their learning. Potential cultural influences should also be considered carefully, to explore the enablers of effective learning fully. By prioritizing students' use of higher cognitive processes, students in this study showed evidence of having been equipped with the skills necessary for life after graduation.

\section{REFERENCES}

Altbach, P. G., Reisberg, L., \& Rumbley, L. E. (2009). Trends in global higher education: Tracking an academic revolution. Report for the UNESCO 2009 World Conference on Higher Education, Retrieved from Paris, France:

Ananda, A. (1997). Teacher questioning and learning outcomes in several Indonesian classrooms. (MEd), University of Tasmania, Launceston. 
Ausubel, D. P. (1968). Educational psychology: A cognitive view. New York: Holt, Rinehart and Winston.

Baird, J. R. (1988). Quality: What should make higher education "higher"? Higher Education Research \& Development, 7(2), 141-152.

Beattie, V., Collins, B., \& McInnes, B. (1997). Deep and surface learning: A simple or simplistic dichotomy? Accounting Education: An International Journal, 6(1), 1-12. doi:http://dx.doi.org/10.1080/096392897331587

Bergmann, J., \& Sams, A. (2012). Flip your classroom: Reach Every student in every class every day. Washington: International Society for Technology in Education.

Bhabha, H. K. (1983). The other question: Stereotype, discrimination and the discourse of colonialism. London and New York: Routledge.

Biggs, J. (1978). Individual and group differences in study processes. British Journal of Educational Psychology, 48, 266-279.

Biggs, J. (1985). The role of meta-learning in study processes. British Journal of Educational Psychology, 12(1), 73-85.

Biggs, J. (1987). Student approaches to learning and studying. Melbourne: Australian Council for Educational Research.

Biggs, J. (1989a). Approaches to the enhancement of tertiary teaching. Higher Education Research $\mathcal{E}$ Development, 8(1), 7-25. doi:http://dx.doi.org/10.1080/0729436890080102

Biggs, J. (1989b). Assessing student approaches to learning. Australian Psychologist, $\quad$ 23(2), 197-206. doi:http://dx.doi.org/10.1080/00050068808255604

Biggs, J. (1999). Teaching for quality learning at University. Buckingham, UK: Society for Research into Higher Education.

Biggs, J. (2003). Teaching for quality learning at university (2nd ed.). Berkshire: The Society for Research into Higher Education \& Open University Press.

Biggs, J., \& Collis, K. (1982). Evaluating the quality of learning: The SOLO taxonomy. New York: Academic Press.

Biggs, J., Kember, D., \& Leung, D. Y. P. (2001). The revised two-factor Study Process Questionnaire: R-SPQ-2F. British Journal of Educational Psychology, 71(1), 133-149. 
Biggs, J., \& Rihn, B. (1984). The effects of the intervention on deep and surface approach to learning. In J. Kirby (Ed.), Cognitive Strategies and Educational Performance (pp. 279-293). New York: Academic Press.

Biggs, J., \& Tang, C. (2011). Teaching for quality learning at university Retrieved from http://atrobe.eblib.com.au/patron/FullRecord.aspx?p=798265

Boyce, G., Williams, S., Kelly, A., \& Yee, H. (2001). Fostering deep and elaborative learning and generic (soft) skill development: The strategic use of case studies in accounting education. Accounting Education: An International Journal, 10(1), 37-60. doi:http://dx.doi.org/10.1080/09639280121889

Brine, J., Wilson, I., \& Roy, D. (2007). Using Moodle and other software tools in EFL courses in a Japanese IT university. Paper presented at the Seventh International Conference on Computer and Information Technology.

Campbell, A. (2012). Enhancing student engagement through practice experience in social work education: The social work studio Higher Education Research $\mathcal{E}$ Development, 31(6), 773-784. doi:http://dx.doi.org/10.1080/07294360.2012.670211

Cheng, X. (2000). Asian students' reticence revisited. System, 28(3), 435-446. doi:http://dx.doi.org/10.1016/S0346-251X(00)00015-4

Choo, P. G. S. (2005). Assessing the approaches to learning of Malaysian students. Jurnal Pendidikan, 25, 133-150.

Cohen, L., Manion, L., \& Morrison, K. (2011). Research methods in education (7th ed.). Oxon, OX: Routledge.

Creswell, J. W. (2009). Research design: Qualitative, quantitative, and mixed methods approaches (3rd ed.). Thousand Oaks, CA: Sage.

Creswell, J. W., \& Clark, V. L. P. (2011). Designing and conducting mixed methods research. Thousand Oaks, CA: Sage.

Cronjé, J. C. (2011). Using Hofstede's cultural dimensions to interpret crosscultural blended teaching and learning Computers E Education, 56, 596603.

Cuthbert, P. F. (2005). The student learning process: Learning styles or learning approaches? Teaching in Higher Education, 10(2), 235-249. doi:10.1080/13562510420000337972

Dang, T. T. (2012). Learner autonomy perception and performance: A study on Vietnamese students in online and offline learning environments. (PhD), La Trobe University. 
Dardjowidjojo, S. (2001). Cultural constraints in the implementation of learner autonomy: The case of Indonesia. Southeast Asian Education. Southeast Asian Education, 2(20), 309-322.

Dardjowidjojo, S. (2006). The implementability of western approaches in the eastern societies. Indonesian Journal of English Language Teaching, 2(1), 120.

Deutsch, N. (2005). Project, problem, and inquiry-based learning. Retrieved from http://www.nelliemuller.com/project.problem.and.inquirybased.learning.htm

Dharma, D. S. (1997). Accounting students' learning conceptions, approaches to learning, and the influence of the learning-teaching context on approaches to learning. Accounting Education: An International Journal, 6(2), 125-146. doi:http://dx.doi.org/10.1080/096392897331532

Echa. (2008, February 22, 2008). Koh ngomong (Being reluctant to speak). Retrieved from http://seikatpadi.blogspot.com.au/2008_02_01_archive.html

Elsegood, S. (2006). Teaching critical thinking in an English for Academic Purposes program using a 'Claims and Supports' approach. Retrieved March 10, 2010, from Indonesia Australia Language Foundations

Elsegood, S., \& Rahimi, A. (2009). Using computer supported reasoning mapping to teach EFL learners critical reasoning and academic writing. AsiaCall Online Journal, 4(1), 81-102.

Emilia, O., Bloomfield, L., \& Rotem, A. (2012). Measuring students' approaches to learning in different clinical rotations. BMC Medical Education, 12, 1-6. doi:10.1186/1472-6920-12-114

Emilia, O., \& Mulholland, H. (1991). Approaches to learning of students in an Indonesian medical school. Medical Education, 25, 462-470.

English, L., Luckett, P., \& Mladenovich, R. (2004). Encouraging a deep approach to learning through curriculum design. Accounting Education, 13(4), 461488. doi:http://dx.doi.org/10.1080/0963928042000306828

Entwistle, N. (1991). Approaches to learning and perception of the learning environment. Higher Education, 22, 201-204.

Entwistle, N. (2004). Teaching-learning environments to support deep learning in contrasting subject areas. Talk at University of Leeds.

Entwistle, N. (2009). Teaching for understanding at university: Deep approaches and distinctive ways of thinking. London: Palgrave Macmillan. 
Entwistle, N., Hanley, M., \& Hounsell, D. (1979). Identifying distinctive approaches to studying. Higher Education, 33, 213-218.

Entwistle, N., \& Ramsden, P. (1983). Understanding student learning. ACT, Australia: Croom Helm Ltd.

Entwistle, N., \& Tait, H. (1990). Approaches to learning, evaluations of teaching, and preferences for contrasting academic environments Higher Education, 19, 169-194.

Fang, T. (2003). A critique of Hofstede's fifth national culture dimension. International Journal of Cross Cultural Management, 3(3), 347-368.

Feletti, G. (1993). Inquiry based and problem based learning: How similar are these approaches to Nursing and Medical Education? Higher Education $\begin{array}{llll}\text { Research } & \mathcal{E} & \text { Development, }\end{array}$ doi:http://dx.doi.org/10.1080/0729436930120203

Gredler, M. E. (1997). Strategies of contextual teaching and learning. Retrieved from

http://www.personal.psu.edu/users/m/a/mab375/Comps/Knowledge Base/thermodl/constrct.htm

Greene, J. C., Caracelli, V. J., \& Graham, W. F. (1989). Toward a conceptual framework for mixed-method evaluation designs. Educational Evaluation and Policy Analysis, 11(3), 255-274.

Hadisantosa, N., Huong, T. T. T., Johnstone, R., Keyuravong, S., \& Lee, W. (2010). Learning through English: Policies, challenges and prospects. Retrieved from Malaysia: http://www.britishcouncil.org/publication_1__learning_through_english.pdf

Hadisaputra, P., \& Santosa, M. H. (2008). Meningkatkan kemampuan menulis mahasiswa dalam mata kuliah Writing III melalui pemanfaatan media blog atau jurnal online (Improving students' writing ability through blogs or online journals). Research. Universitas Pendidikan Ganesha. Singaraja.

Halawi, L., Mccharty, R., \& Muoghalu, N. (2009). Student approaches to learning: An exploratory study. Issues in Information System, X(1), 13-21.

Hall, M., Ramsay, A., \& Raven, J. (2004). Changing the learning environment to promote deep learning approaches in first-year Accounting students. Accounting Education: An International Journal, 13(4), 489-505. doi:http://dx.doi.org/10.1080/0963928042000306837

Hamdan, N., McKnight, P. E., McKnight, K., \& Arfstrom, K. M. (2013). A review of flipped learning. Arlington: Flipped Learning Network. 
Hardiyanto. (2010). The development of core competencies at higher education: A suggestion model for universities in Indonesia. International Journal for Educational Studies, 3(1), 11-22.

Hay, D. B. (2007). Using concept maps to measure deep, surface and nonlearning outcomes. Studies in Higher Education, 32(1), 39-57. doi:http://dx.doi.org/10.1080/03075070601099432

Hofstede, G. (1980). Culture's consequences: International differences in work-related values. Beverly Hills, CA: Sage Publications.

Hofstede, G. (1986). Cultural differences in teaching and learning. International Journal of Intercultural Relations, 10, 301-320.

Hofstede, G. (1991). Cultures and organizations: Software of the mind. London: McGraw-Hill.

Hofstede, G. (2001). Culture's consequences: Comparing values, behaviors, institutions and organizations across nations. Thousand Oaks, California: Sage Publications.

Hofstede, G. (2011). Dimensionalizing cultures: The Hofstede model in context. Online Readings in Psychology and Culture, 2(1), 1-26. doi:http: //dx.doi.org/10.9707/2307-0919.1014

Hofstede, G., Hofstede, G. J., \& Minkov, M. (2010). Cultures and organizations: Software of the mind (3rd ed.). New York: McGraw-Hill.

Hsieh, P.-C. (2009). The effects of computer-mediated communication by a course management system (Moodle) on EFL Taiwanese student's English reading achievement and perceptions (Doctor of Education Dissertation), La Sierra University, California.

Iftanti, E. (2012). A survey of English reading habits of EFL students in Indonesia. TEFLIN, 23(2), 149-164.

Ismail, S. (2009). Accounting student's learning approaches and impact on academic performance. Jurnal Akuntansi dan Keuangan Indonesia, 6(2), 140151.

Joy, S., \& Kolb, D. A. (2009). Are there cultural differences in learning style? International Journal of Intercultural Relations, 33, 69-85. doi:10.1016/j.ijintrel.2008.11.002

Jürgens, S., Emilia, O., \& Widyandana. (2009). Relationship between learning approach and motivation to learn among medical students at Universitas Gadjah Mada. Jurnal Pendidikan Kedokteran dan Profesi Kesehatan Indonesia, 1, 26-31.

Journal on English as a Foreign Language, 7(2), 183-208

Copyright @ 2017 by JEFL, p-ISSN 2088-1657; e-ISSN 2502-6615 
Justice, C., Rice, J., Warry, W., Inglis, S., Miller, S., \& Sammon, S. (2007). Inquiry in higher education: Reflections and directions on course design and teaching methods. Innovative Higher Education, 31, 201-214.

Kember, D., \& Gow, L. (1989). A model of student approaches to learning encompassing ways to influence and change approaches. Instructional Science, 18(263-288).

Lang, J. C. (2017). The flipped classroom for teaching millennials: A competency-based pedagogical approach. Creative Education, 8, 15711589. doi:https://doi.org/10.4236/ce.2017.810108

Laurillard, D. (1984). Learning from problem solving. In F. Marton, D. J. Hounsell, \& N. Entwistle (Eds.), The Experience of Learning (pp. 124-143). Edinburgh: Scottish Academic Press.

Lewis, C. C., \& George, J. F. (2008). Cross-cultural deception in social networking sites and face-to-face communication. Computers in Human Behavior, 24, 2945-2964. doi:10.1016/j.chb.2008.05.002

Lie, A. (2007). Education policy and EFL curriculum in Indonesia: Between the commitment to competence and the quest for higher test scores. TEFLIN, 18(1), 1-14.

Lucas, U. (2001). Deep and surface approaches to learning within introductory accounting: a phenomenographic study. Accounting Education: An International Journal, 10(2), 161-184. doi:http://dx.doi.org/10.1080/09639280110073443

Lucas, U., \& Mladenovic, R. (2004). Approaches to learning in accounting education. Accounting Education: An International Journal, 13(4), 399-407. doi:http://dx.doi.org/10.1080/0963928042000306783

Marcellino, M. (2008). English language teaching in Indonesia: A continuous challenge in education and cultural diversity. TEFLIN Journal, 19(1), 5769.

Marton, F. (1981). Phenomenography - Describing conceptions of the world around us. Instructional Science, 10, 177-200.

Marton, F., \& Säljo, R. (1976). On qualitative differences in learning - I: Outcome and process. British Journal of Psychology, 46(1), 4-11.

Marton, F., \& Säljo, R. (1984). Approaches to learning. In F. Marton, D. J. Hounsell, \& N. J. Entwistle (Eds.), The experience of learning (pp. 36-55). Edinburgh: Scottish Academic Press. 
Masduqi, H. (2011). Critical thinking skills and meaning in English language teaching. TEFLIN Journal, 22(2), 185-200.

McKenzie, J. (1998). Grazing the net: Raising a generation of free range students. Retrieved from http://www.fno.org/text/grazing.html

Nandi, D., Hamilton, M., Chang, S., \& Balbo, S. (2012). Evaluating quality in online asynchronous interactions between students and discussion facilitators. Australasian Journal of Educational Technology, 28(4), 684-702.

National Research Council. (2012). Education for life and work: Developing transferable knowledge and skills in the 21st century. Washington, DC: The National Academies Press.

Nesama, E. G. (2012, January 6, 2012). Sejarah kurikulum Indonesia (History of the Indonesian curriculum). Retrieved from http: //ekagurunesama.blogspot.com.au/2012/01/sejarah-kurikulumindonesia.html

Nilan, P. (2003). Teachers' work and schooling in Bali. International review of education, 49(6), 563-584.

Novera, I. A. (2004). Indonesian postgraduate students studying in Australia: An examination of their academic, social, and cultural experiences. International Education Journal, 5(4), 475-487.

On, L. W. (1996). The cultural context for Chinese learner: Conceptions of learning in the Confucian tradition. In D. A. Watkins \& J. B. Biggs (Eds.), The Chinese Learner: Cultural, Psychological, and Contextual Influences (pp. 25-41). Hong Kong/Melbourne: Comparative Education Research Centre/Australian Council for Educational Research.

Phusavat, K., Ketsarapong, S., Ooi, K.-B., \& Shyu, S. H. P. (2012). Sustaining higher education reforms: knowledge and policy implications learned from Thailand. International Journal of Educational Management, 26(3), 284301. doi:http://dx.doi.org/10.1108/09513541211213354

Pikkert, J. J. J., \& Foster, L. (1996). Critical thinking skills among Third Year Indonesian English students. RELC Journal, 27(2), 56-64.

Putrayasa, I. B. (2001). Pembelajaran bahasa Indonesia berbasis inkuiri (An inquirybased learning for Indonesian subject). Paper presented at the KIP BIPA, Bali, Indonesia. http://www.ialf.edu/kipbipa/papers/BPutrayasa.doc

Ramsden, P. (1992). Learning to teach in higher education. London: Routledge.

Ramsden, P. (2003). Learning to teach in higher education (2nd ed.). New York, NY: RoutledgeFalmer. 
Rohaniawati, D. (2011). Memahami konsep belajar (Understanding the concept of learning). Retrieved from http://dikti.go.id/Index.php?option=com_content\&view=article\&id=2147: memahami-konsep-belajar\&catid=159:artikel-kontributor

Said, E. (1977). Orientalism. London: Penguin.

Santosa, M. H. (2008). Modeling and reflection application aided by video recording to improve students' competency in TEYL in English education department of Ganesha University of Education. Paper presented at the International Seminar and Workshop on EYL, Muhammadiyah University of Gresik, Indonesia.

Santosa, M. H. (2012). Deeper learning for digital natives. Retrieved from http:/puzzleminds.com/deeper-learning-for-digital-natives/

Santosa, M. H. (2013). An Investigation into the Relationship between Students' Approaches to Learning and Learning Outcomes in an Indonesian EnglishLearning Context. (PhD), La Trobe University, Melbourne.

Sayuti, M. (2009). Generic skills in Indonesian vocational school: The context, the reality, and the future's challenges. Retrieved from http:/blog.uad.ac.id/sayuti/2009/05/30/generic-skills-in-indonesian-smk/

Schmeck, R. (1983). Learning styles of college students. In R. Dylon \& R. Schmeck (Eds.), Individual differences in cognition (pp. 233-279). New York: Academic Press.

Signorini, P., Wiesemes, R., \& Murphy, R. (2009). Developing alternative frameworks for exploring intercultural learning: A critique of Hofstede's cultural difference model. Teaching in Higher Education, 14(3), 253-264. doi:10.1080/13562510902898825

Sincero, P. (2006). What is inquiry-based learning? Retrieved from http://www.inquirylearn.com/Anquirydef.htm

Suharmanto. (2003). Learning autonomy: A way to improve English language teaching (ELT) in Indonesia. TEFLIN Journal, 14(1).

Sunarta, W. (2009, November 21, 2009). [Teroka] Kritik mati bila Bali "Koh Ngomong" (A deadly criticism on if Balinese "is reluctant to speak"). Retrieved from http://cabiklunik.blogspot.com.au/2009/11/teroka-kritikmati-bila-bali-koh.html

Sund, R. B., \& Trowbridge, L. W. (1967). Teaching science by inquiry in the Secondary School. Columbus, Ohio: C. E. Merill Publishing Company. 
Taher, A. M. M. H., \& Jin, C. (2011). Assessing learning approaches of Chinese local MBA students: An investigation using the Revised Two-factor Study Process Questionnaire (R-SPQ-2F). Educational Research and Reviews, 6(19), 974-978. doi:10.5897 ÆRR11.152

Tambunan, L. A. (2011). Dampak soft skills di dalam pendidikan perguruan tinggi dalam menunjang pengembangan SDM di Indonesia (Effects of soft skills in higher education to support the Indonesian human resources). Retrieved from http://dikti.go.id/index.php?option=com_content\&view=article\&id=1914: dampak-soft-skills-di-dalam-pendidikan-perguruan-tinggi-dalammenunjang-pengembangan-sdm-di-indonesia\&catid=159:artikelkontributor

Tantrayana, G. (2012, December 19, 2012). Merebut balung tanpa isi (Quarelling on a bone without meat). Retrieved from http://artadharma.blogspot.com.au/2012/12/merebut-balung-tanpaisi.html

Teddlie, C., \& Tashakori, A. (2003). Major issues and controversies in the use of mixed-methods in the social and behavioural sciences. In C. Teddlie \& A. Tashakori (Eds.), Handbooks of mixed-methods in social and behavioural research (pp. 3-50). Thousand Oaks, CA: Sage Publications, Inc.

Thomas, P., \& Bain, J. (1984). Contextual differences of learning approaches: The effects of assessment. Human Learning, 3, 227-240.

Thowfeek, M. H., \& Jaafar, A. (2012). Instructor's view about implementation of e-learning system: An analysis based on Hofstede cultural dimensions. Procedia - Social and Behavioral Sciences, 65, 961-967. doi:10.1016/j.sbspro.2012.11.227

Trigwell, K., \& Prosser, M. (1991). Improving the quality of student learning: The influence of learning context and student approaches to learning on learning outcomes. Higher Education, 22(3), 251-266.

Uysal, H. H. (2010). A critical review of the IELTS writing test. ELT Journal, 64(3), 314-320.

Volkert, D. (2012, October 2012). Inquiry based learning: Faculty perspective. Nevada RNformation, p. 15.

Warren, D., \& Griffiths, D. (2006). Editorial. Investigations in university teaching and learning, 4(1), 1-5.

Watkins, D. (1983). Depth processing and the quality of learning outcome. Instructional Science, 12, 49-58.

Journal on English as a Foreign Language, 7(2), 183-208

Copyright @ 2017 by JEFL, p-ISSN 2088-1657; e-ISSN 2502-6615 
Watkins, D. (1996). Learning theories and approaches to research: A crosscultural perspective. In D. A. Watkins \& J. B. Biggs (Eds.), The Chinese learner: cultural, psychological, and contextual influences (pp. 3-24). Hong Kong Melbourne: Comparative Education Research Centre/Australian Council for Educational Research.

Watkins, D., \& Biggs, J. (1996). The Chinese learner in retrospect. In D. A. Watkins \& J. B. Biggs (Eds.), The Chinese learner: Cultural, psychological and contextual influences (pp. 269-285). Hong Kong/Melbourne: Comparative Education Research Centre/Australian Council for Educational Research.

Wilson, J., \& Jan, L. W. (2003). Focus on inquiry: A practical approach to integrated curriculum planning. Carlton South, VIC: Curriculum Corporation.

Wittrock, M. C. (1974). Learning as a generative process. Educational Psychologist, 11, 87-95.

Yamauchi, M. (2010). Integrating internet technology into the EFL classroom: A case study. International Journal of Pedagogies and Learning, 5(2), 3-19.

Yorra, M. L. (2012). The development of self-efficacy and self-esteem in pharmacy students based on experiential education. (Doctor of Education), Northeastern University, Boston, Massachusetts.

Zhu, C., \& Zou, H. (2011). Inquiry based learning on blended learning for undergraduate. Paper presented at the International Conference on eEducation, Entertainment and e-Management, Bali, Indonesia.

\section{Author's Brief CV}

Made Hery Santosa is a teaching staff at Universitas Pendidikan Ganesha, Singaraja, Bali, Indonesia. He serves as Director of Program Development in Indonesia Technology Enhanced Language Learning (iTELL) Association. He has extensively presented in numerous ELT conferences and workshops. His main interests include Education, ELT, Technology-based Learning, and Learner Autonomy. 